\title{
Analysis of strawberry promising varieties and selected forms by resistance to red stele root rot using molecular markers
}

\author{
Alexander Lyzhin* and Irina Luk'yanchuk \\ "I.V. Michurin Federal Scientific Center", 393774 Michurinsk, Russian Federation
}

\begin{abstract}
The analysis of the allelic state of the Rpf1 red stele root rot gene in 14 promising foreign strawberry varieties and 6 selected forms of the I.V. Michurin FSC breeding was completed. The Rpfl gene in a heterozygous state was identified in strawberry forms 61-15 (Bylinnaya $\times$ Olimpiyskaya nadezhda), 69-29 (Feyerverk $\times$ Bylinnaya), and 72-71 (Privlekatelnaya $\times$ Bylinnaya), which makes it possible to recommend them for involvement in breeding work to create resistant to $P$. fragariae var. fragariae strawberry varieties. Strawberry varieties Lebedushka, Elianny, Florence, Malwina, Monterey, Polka, Verona, Vima Tarda Asia, Chamora Turusi, Clery, Flamenco, Salsa and Symphony, and selected forms 56-5 (Gigantella Maxim $\times$ Privlekatelnaya), 69-42 (Feyerverk $\times$ Bylinnaya) and 35-16 (922-67 $\times$ Maryshka) have a recessive homozygous genotype.
\end{abstract}

\section{Introduction}

Resistance to fungal pathogens is one of the most important traits of any plant variety. Strawberry is susceptible to many diseases that affect all parts of plants: leaves, roots, flowers, fruits, etc. One of the most dangerous diseases of strawberry is diseases of the root system. Among them is red stele root rot, the causative agent of which is the quarantine phytopathogen Phytophthora fragariae var. fragariae Hickman [1-3]. In strawberry plants affected by red stele root rot, the death of lateral feeding and adventitious roots is observed with the formation of pathogen oospores in the affected tissues, inhibition of growth and wilting $[4,5]$.

Strawberry resistance to red stele root rot is due to the presence in the genome of several race-specific genes, of which the $R p f 1, R p f 2$, and $R p f 3$ genes are the most important $[6,7]$.

The purpose of this study was the molecular genetic analysis of the allelic state of the Rpfl gene in promising strawberry varieties and selected forms for identification of resistant to $P$. fragariae var. fragariae genotypes.

\footnotetext{
* Corresponding author: Ranenburzhetc@yandex.ru
} 


\section{Materials and methods}

The studies were carried out in 2020-2021. Biological material was represented by widespread industrial strawberry varieties, introduced from various ecological and geographical regions of growth and promising strawberry hybrid seedlings obtained at the "I.V. Michurin Federal Scientific Center" (Table 1).

Table 1. Analyzed strawberry varieties and selected forms

\begin{tabular}{|c|c|c|}
\hline $\begin{array}{l}\text { Variety / } \\
\text { form }\end{array}$ & Crossing combination & Originator \\
\hline Lebedushka & No information available & Ukraine \\
\hline Asia & NF421 & New Fruits, Italy \\
\hline $\begin{array}{l}\text { Chamora } \\
\text { Turusi }\end{array}$ & No information available & Japan \\
\hline Clery & Sweet Charlie $\times$ Onebor & Consorzio Italiano Vivaisti, Italy \\
\hline Elianny & No information available & Gebr. Vissers, Netherlands \\
\hline Flamenco & Evita $\times$ EMR77 & $\begin{array}{l}\text { East Malling Research Station, } \\
\text { United Kingdom }\end{array}$ \\
\hline Florence & $\begin{array}{l}{[\text { Tioga } \times(\text { Red Gauntlet } \times} \\
(\text { Wiltguard } \times \text { Gorella }))] \times \\
(\text { Providence } \times \text { self })\end{array}$ & MEIOSIS LTD, United Kingdom \\
\hline Malwina & $\begin{array}{l}\text { Sophie } \times \text { clone Schimmelpfeng, } \\
\text { Weihenstefan }\end{array}$ & Peter Stoppel, Germany \\
\hline Monterey & Cal. 27-85.06 × Albion & University of California Davis, USA \\
\hline Polka & Unduka $\times$ Sivetta & $\begin{array}{l}\text { Plant Research International - WUR, } \\
\text { Netherlands }\end{array}$ \\
\hline Salsa & No information available & Fresh Forward B.V., Netherlands \\
\hline Symphony & Rhapsody $\times$ Holiday & $\begin{array}{l}\text { Mylnefield Research Services Ltd, } \\
\text { United Kingdom }\end{array}$ \\
\hline Verona & No information available & Fragolà, Italy \\
\hline Vima Tarda & Vima Zanta $\times$ Vicoda & $\begin{array}{l}\text { Vissers International BV, } \\
\text { Netherlands }\end{array}$ \\
\hline $35-16$ & $922-67 \times$ Maryshka & \multirow{6}{*}{$\begin{array}{l}\text { "I.V. Michurin Federal Scientific } \\
\text { Center", Russia }\end{array}$} \\
\hline $56-5$ & $\begin{array}{l}\text { Gigantella Maxim } \times \\
\text { Privlekatelnaya }\end{array}$ & \\
\hline $61-15$ & $\begin{array}{l}\text { Bylinnaya } \times \text { Olimpiyskaya } \\
\text { nadezhda }\end{array}$ & \\
\hline $69-29$ & \multirow{2}{*}{ Feyerverk $\times$ Bylinnaya } & \\
\hline $69-42$ & & \\
\hline $72-71$ & Privlekatelnaya $\times$ Bylinnaya & \\
\hline
\end{tabular}

The allelic state of the Rpfl gene was identified by DNA analysis using diagnostic markers OPO-16C (RAPD) [8] and R1A (SCAR) [9].

The RAPD marker OPO-16C is represented by amplicons from 400 to $2000 \mathrm{bp}$. The $438 \mathrm{bp}$ amplicon is linked to the $R p f 1$ gene (non-functional $r p f 1$ allele). Other products of the OPO-16C marker are amplified regardless of the allelic state of the Rpfl gene [8, 10]. The SCAR marker R1A is represented by a $285 \mathrm{bp}$ amplicon and linked to the functional allele Rpf1 [9]. The use of a combination of markers OPO-16C and R1A makes it possible to identify the allelic state of the $R p f 1$ gene: the presence of the R1A marker and the absence of the OPO-16C marker indicates a dominant homozygous genotype, the presence 
of both markers indicates a heterozygous genotype, the presence of the OPO-16C marker and the absence of the R1A marker, and the absence of both markers, indicates a recessive homozygous genotype [11].

Polymerase chain reaction (PCR) was performed in T100 Thermal Cycler (BioRad) according to the previously described programs $[10,12]$.

Amplification products were separated by electrophoretic method in agarose gel (agarose concentration - 2\%, running buffer - 1x TBE). Amplicon sizes estimated were performed using the Gene Ruler 100 bp DNA Ladder (Thermo Fisher Scientific).

\section{Results and discussion}

According to the research, the OPO-16C marker was identified in the strawberry varieties Lebedushka, Elianny, Florence, Malwina, Monterey, Polka, Verona and Vima Tarda, and selected strawberry hybrid forms 56-5 (Gigantella Maxim $\times$ Privlekatelnaya), 61-15 (Bylinnaya $\times$ Olimpiyskaya nadezhda), 69-29 (Feyerverk $\times$ Bylinnaya) and 72-71 (Privlekatelnaya $\times$ Bylinnaya). Examples of the obtained electrophoretic profiles of marker fragments are shown in Figure 1(a), results of the analysis are shown in Table 2.
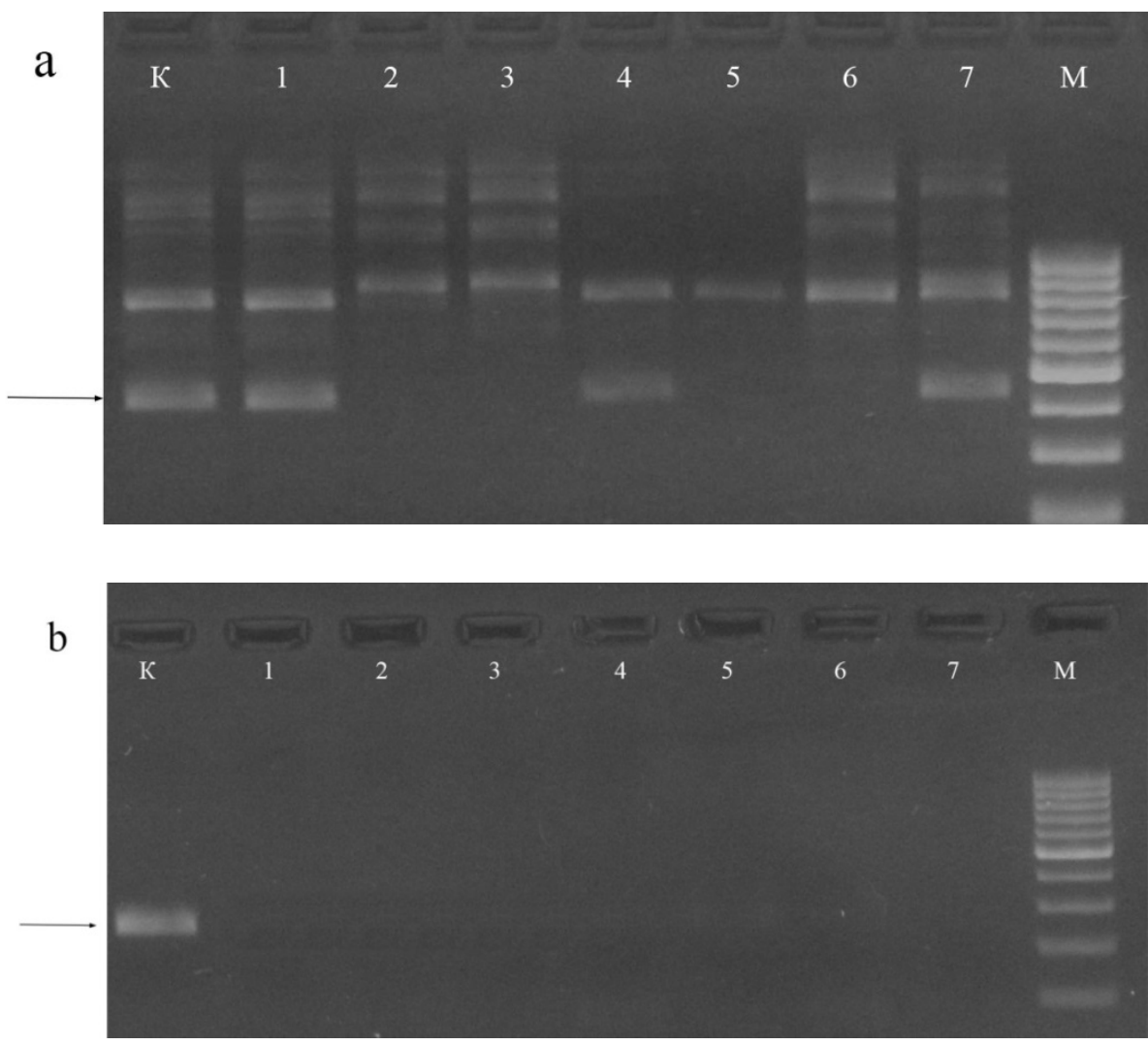

Fig. 1. Electrophoretic profiles of marker fragments OPO-16C (a) and SCAR-R1A (b) Rpfl gene in strawberry varieties $\mathrm{K}$ - control (F. virginiana subsp. platypetala), 1 - Malwina, 2 - Asia, 3 - Chamora Turusi, 4 - Lebedushka, 5 - Flamenco, 6 - Salsa, 7 - Verona, M - Molecular weight marker

The SCAR-R1A marker was identified in selected strawberry forms 61-15 (Bylinnaya $\times$ Olimpiyskaya nadezhda), 69-29 (Feyerverk $\times$ Bylinnaya) and 72-71 (Privlekatelnaya $\times$ 
Bylinnaya). In the analyzed promising strawberry varieties, the SCAR-R1A marker is absent. Examples of the obtained electrophoretic profiles of marker fragments are shown in Figure 1(b), results of the analysis are shown in Table 2.

Table 2. Allelic polymorphism of the Rpfl red stele root rot resistance gene in strawberry varieties and hybrid forms ( 1 - allele is present, 0 - allele is absent $)$

\begin{tabular}{|c|c|c|c|}
\hline Genotype & $\begin{array}{l}\text { Marker } \\
\text { SCAR-R1A }\end{array}$ & $\begin{array}{l}\text { Marker } \\
\text { OPO-16C }\end{array}$ & Putative genotype \\
\hline Lebedushka & 0 & 1 & rpflrpfl \\
\hline Asia & 0 & 0 & rpflrpf1 \\
\hline Chamora Turusi & 0 & 0 & rpflrpfl \\
\hline Clery & 0 & 0 & rpflrpf1 \\
\hline Elianny & 0 & 1 & rpflrpf1 \\
\hline Flamenco & 0 & 0 & rpflrpfl \\
\hline Florence & 0 & 1 & rpflrpfl \\
\hline Malwina & 0 & 1 & rpflrpfl \\
\hline Monterey & 0 & 1 & rpflrpfl \\
\hline Polka & 0 & 1 & rpflrpf1 \\
\hline Salsa & 0 & 0 & rpflrpf1 \\
\hline Symphony & 0 & 0 & rpflrpfl \\
\hline Verona & 0 & 1 & rpflrpfl \\
\hline Vima Tarda & 0 & 1 & rpflrpf1 \\
\hline $56-5$ & 0 & 1 & rpflrpfl \\
\hline $61-15$ & 1 & 1 & Rpflrpfl \\
\hline $69-29$ & 1 & 1 & Rpflrpf1 \\
\hline $69-42$ & 0 & 0 & rpflrpf1 \\
\hline $72-71$ & 1 & 1 & Rpflrpfl \\
\hline $35-16$ & 0 & 0 & rpflrpfl \\
\hline
\end{tabular}

According to the obtained data, the analyzed strawberry varieties are characterized by a recessive homozygous state of the Rpfl gene: in the varieties Lebedushka, Elianny, Florence, Malwina, Monterey, Polka, Verona, and Vima Tarda is present only the OPO16C marker; the varieties Asia, Chamora Turusi, Clery, Flamenco, Salsa and Symphony do not have SCAR-R1A and OPO-16C markers. Selected strawberry forms 61-15 (Bylinnaya $\times$ Olimpiyskaya nadezhda), 69-29 (Feyerverk $\times$ Bylinnaya) and 72-71 (Privlekatelnaya $\times$ Bylinnaya) are characterized by a heterozygous genotype for the Rpfl gene. Strawberry seedlings 56-5 (Gigantella Maxim $\times$ Privlekatelnaya), 69-42 (Feyerverk $\times$ Bylinnaya) and 35-16 (922-67 $\times$ Maryshka) have a recessive homozygous genotype (rpflrpf1).

\section{Conclusion}

Thus, as a result of the research, we identified the allelic state of the Rpfl gene in 14 promising strawberry varieties of foreign breeding and 6 strawberry selected forms created in the I.V. Michurin FSC. The Rpfl gene in a heterozygous state was identified in strawberry hybrid forms 61-15 (Bylinnaya $\times$ Olimpiyskaya nadezhda), 69-29 (Feyerverk $\times$ Bylinnaya) and 72-71 (Privlekatelnaya $\times$ Bylinnaya), which makes it possible to recommend them for involvement in breeding work to create resistant to $P$. fragariae var. fragariae strawberry varieties. 


\section{References}

1. K.J.D. Hughes, A.J. Inman, D.E.L. Cooke, EPPO Bulletin, 30(3-4), 533-538 (2000)

2. W. Chong, Z. Rong, H. Zhen, Z. Qingtian, Plant Diseases \& Pests, 11(1), 10-12 (2020)

3. J.R. Xiao, P.C. Chung, H.Y. Wu, Q.H. Phan, J.L.A. Yeh, M.T.K. Hou, Plants, 10(1), 31 (2021) https://doi.org/10.3390/plants10010031

4. A. Sasnauskas, R. Rugienius, D. Gelvonauskiené, I. Zalunskaitė, G. Stanienè, T. Siksnianas, V. Stanys, C. Bobinas, Acta Hortic., 760, 165-169 (2007) https://doi.org/10.17660/A ctaHortic.2007.760.21

5. A.C. Newton, J.M. Duncan, N.H. Augustin, D.C. Guy, D.E.L. Cooke, Plant pathology, 59(3), $472-479$ (2010) https://doi.org/10.1111/j.1365-3059.2010.02273.x

6. W.E. Van de Weg, Theoretical and Applied Genetics, 94(3-4), 445-451 (1997) https://doi.org/10.1007/s001220050435

7. V.M. Whitaker, Journal of Berry Research, 1, 115-127 (2011) https://doi.org/10.3233/BR-2011-013

8. K.M. Haymes B. Henken, T.M. Davis, W.E. van de Weg, Theor. Appl. Genet., 94(8), 1097-1101 (1997) https://doi.org/10.1007/s001220050521

9. K.M. Haymes, W.E. Van de Weg, P. Arens, J.L. Maas, B. Vosman, A.P.M. Den Nijs, J. Amer. Soc. Hort. Sci., 125(3), 330-339 (2000) https://doi.org/10.21273/JASHS.125.3.330

10. A.S. Lyzhin, I.V. Luk'yanchuk, Proceedings of the National Academy of Sciences of Belarus. Agrarian Series, 58(3), 311-320 (2020) https://doi.org/10.29235/1817-72042020-58-3-311-320

11. M. Sturzeanu, M. Coman, M. Ciuca, I. Ancu, D. Cristina, A.G. Turcu, Acta Hortic., 1139, 107-112 (2016) https://doi.org/10.17660/ActaHortic.2016.1139.19

12. I.V. Luk'yanchuk, A.S. Lyzhin, I.I. Kozlova, Vavilov Journal of Genetics and Breeding, 22(7), 795-799 (2018) https://doi.org/10.18699/VJ18.423 